\title{
Working through the Past: The Victory of Adwa Revisited
}

\author{
Kebadu Mekonnen Gebremariam*
}

\begin{abstract}
If working through the past is going to heal a nation, it has to come from within. This paper explores two senses of historical responsibility: the responsibility we bear for healing the wounds of the past or working-off-the-past, and the responsibility we may have in fulfilling the promises of the defining moments of the past (redeeming or cashing in on the past). By utilizing these two conceptual tools, the paper carves out a normative space Adwa ought to occupy in a just and ethical revitalisation of our collective memories. It argues that the process of coming to terms with divisive historical legacies must pass 'the Adwa test' that it ought to be comprehensively liberating, universalizable, and thus has the ability to translate 'the past as future.' The victory in Adwa passes on the responsibility to birth our future in the image of its Volksgeist or spirit of the people (in the Hegelian sense indicating dialectical unfolding of the self, and not in the Fichtean sense where the past is defined in puritan terms) and by cultivating a national character commensurate with it. This paper posits that engagement with the positive experience of freedom from colonialism and the attendant sense of individual and collective autonomy that Adwa provides is one part of the equation for what Adorno calls "reconciliation" of the subject with object (history). The other part is a genuine recognition of the collective memory that past harm brought forth in the present, which we often reject as inherently unlike us. While Adwa offers the ground we stand on, embracing historical contradictions will serve as a condition for genuine reconciliation. The responsibility to come to terms with, atone for, and rectify the legacies of our history must be underpinned by an equal responsibility to fulfil Adwa's promises.
\end{abstract}

Keywords: Working-off-the-past, collective memory, victory of Adwa, Reconciliation

DOI: https://dx.doi.org/10.4314/ejossah.v17i1.2

*Assistant professor, Department of Philosophy, College of Social Sciences, Addis Ababa University, Email: kebadum@gmail.com, Tel.: +251911990423, P.O. Box 1176/ Addis Ababa

This work is licensed to the publisher under the Creative Commons Attribution-NonCommercialNoDerivs License. 


\section{Introduction to an Ethics of Memory}

What ought we to learn from history? The German philosopher Friedrich Hegel once sneered that " $[t]$ he only thing we learn from history is that we learn nothing from history." His remark is in keeping with David Hume's view that "mankind are so much the same in all times and places that history informs us of nothing new or strange." (1748, Sec. 65) If Hume was right, then human history would be reducible to a Groundhog Day of events where progress is a mere fantasy and everyone who lived in it condemned to die with a whimper like Tolstoy's Ivan Ilyich wondering: "What if my whole life has been wrong?". It is clearly implausible for Hume to declare that the human condition is invariably the same across history. Hegel's thesis, in contrast, is more complex than meets the eye. The underlying thesis of Hegel's philosophy of history is that spirit-as-the-self unfolds dialectically through contradiction and synthesis, where the progress of personal freedom goes hand in hand with social progress. At each stage of history, out of a contradiction between opposing forces something new is alchemized which is irreducible to its composing parts. On charitable reading, Hegel may be seen as essentially saying that we don't learn from history (the past) but follow the inescapable path of growing out of it. One way of tempering Hegel's downplaying remark about lessons from history may be by invoking collective memory as a signifier that the past also dwells with us in the present, whose centrality to informing our current political thoughts and actions is far too evident. If any moment in history signifies progress, then learning from history is inescapable because the past is already built into the present.

History principally seeks to describe reality as it was lived in the past and provide an understanding of the causal chain of events including the interpretation of past events in light of the present. If history is tasked with describing the past, the role of memory seems to be capturing and reliving its sensibility. The Israeli philosopher Avishai Margalit stated that "collective existences are webs of relations based on bonds in which shared memories play a crucial part." (Margalit 2002 , p. 95) But what precise role do shared memories play in either entrenching or breaking the webs of thick relations that people hold dear? When we remember the past, what we remember is principally the moral emotions that they encapsulate. That is especially true of a distant past which, due to its historical significance, is committed to collective memory. What makes us tick is not precisely the episodic experience of the events memorized, or the memory of such events as passed through generations, but rather the memory of how people were made to feel. More importantly, the moral emotions attached to memories of the past - such as the feelings of pride or humiliation, rejection or being recognized 
and accepted, alienation or feeling at home, gratitude or resentment-can be relived as "a way of grappling the sense and sensibility of past events needed for understanding and assessing the things we care about in the present, especially the people we care about." (Margalit 2002, p. 109)

If recent history is any guidance, a blanket recourse to the memory of our checkered past as a bulwark against evil, with the attendant mottos "lest we forget", "lest we'll be condemned to repeat it", has proved to be sterile. The horrors of the Holocaust rightly inspired the "never again" slogan, and yet human cruelty has continued to be visited upon people with incredible frequency and guile. Scientific knowledge allied with a rich imagination has expanded our vision for a better future and has offered both technical and institutional tools for improving our material wellbeing. But the technical progress is equally matched by the increasing utilization of the selfsame tools for chaos and mayhem. Human cruelty permeates our everyday reality so much so that one doesn't even need to count victims of mass atrocities from Cambodia to Rwanda, Bosnia to the Congo, or from Nicaragua to Chile, to prove it. Even those who remember the past are likely to repeat its mistakes, and at times mistakes are repeated precisely because we remember the past. History is replete with atrocities committed in the name of the past. If then malevolence is internal to the human condition in general, it can hardly be rooted out from the hearts and minds of people either through the adoption of advanced technology or by a simple recourse to memory and the attendant appeal to never forget. One reason being that generic declarations like "never forget!" are principally symbolic. Although such declaration appears to be compelling due to its rhetorical flair, it leaves rather undefined which actions should be deemed indispensable for preventing the material conditions for evil from taking root in society. Sufficient attention hasn't been given to the most pertinent question of what specific role that the recourse to collective memory must play for establishing a decent society, which is predicated on just institutions.

Another reason for the sterility of the crude recourse to memory as an antidote for evil is its familiar alignment with the view of the world in binary terms - as good and evil, in the manner that does not recognize ambivalence or nuance. The dichotomy between righteous victims and irredeemable victimizers does not often reflect the relationship between actual human beings who've led all too human lives with all their glory and ugliness. Evidently, the absurdity is even more glaring when the archetypes of good and evil are applied to contrasting groups of people or nations with shared past. Tzvetan Todorov, the wise interlocutor of the history of the twentieth century, forewarned that polar thinking about the past, if anything, deepens the shadows that past crimes continue to cast 
on the present. In Memory as a Remedy for Evil, Todorov wrote that "The memory of the past will serve no purpose if it is used to build an impassible wall between evil and us, identifying exclusively with irreproachable heroes and innocent victims and driving the agent of evil outside the confines of humankind." (Todorov 2010, p. 80) The memory of evil must instead be used to humanize not only the victims (with all their complexity) but also to humanize the perpetrators of unspeakable crimes - without trying to either minimize or let go of their crimesas epitomes of what ordinary human beings are capable of being and doing. For "the line separating good and evil passes not through states, nor between classes, nor between political classes either-but right through every human heart - and through all human hearts. This line shifts. Inside us, it oscillates with the years. And even within hearts overwhelmed by evil, one small bridgehead of good is retained. And even in the best of all hearts, there remains...an unuprooted small corner of evil" (Solzhenitsyn 1974, p. 615). Recognizing this truth about the human condition is a prerequisite for us to be able to isolate the social and political conditions necessary for evil to take root in society.

How do we then recognize when memory is useful in orienting the future and when it is abused? What ought we to remember from the past? Or to put it succinctly, what lessons we ought to draw from the past and what aspect of its memories should occupy the socio-political foreground? What renders some manifestations of reliving the past pathological?

\section{Trauma or catharsis: Revisiting the battles of Jena and Adwa in historical contrast}

"But you must know that only he who fights the darkness within will the day after tomorrow have his own share in the sun."

Odysseus Elytis

One of the central tenets of Freud's theory which later became a common currency amongst psychologists is the concept of the unconscious, where repressed elements of the personality including traumatic memory reside. In understanding the unconscious elements of the human psyche Freud (1974, pp. 30-31, 148-149, \& 204-206) deployed two contrasting images: trauma and catharsis. He envisions that the work of psychoanalysis is to midwife the expression of the affect/emotion associated with a traumatic memory, a process characterized as catharsis. The image of trauma represents the scar that is left behind when painful physical injuries are healed and is revealed when memory cracks open the hidden emotional discharges of insult and humiliation. Contrariwise, the image of catharsis involves 
the process of cleansing the poison dart of insult and humiliation in its entirety, leaving no stain behind. The aim is to recover suppressed memories in the manner that the subject is released from the unconscious toxicity that repressed memories bring. As in individual psychosis, so in public life "recalling the past does not provide its justification, and just like a personal memory, it has to be worked through (durchgearbeitet, in Freud's terminology) (Todorov 2003, p. 173).

We know how trauma manifests in society through the destruction it leaves behind in its wake. At the level of the individual, it makes persons overreact to the slightest provocation to the extent that a present trigger displays close affinity with injury from the past. "Or it displaces that which brought the trauma about with a different object that is somehow associated with the object of the past." (Margalit 2002 , p. 126) When collective trauma is invoked out of loyalty to our ancestors who have suffered under the hands of their tormentors, oftentimes, "it can poison our relationship with the innocent descendants of their oppressors" (Margalit, 2002, p. 110). A feeling of bitterness can easily be exploited by political demagogues who are bent on harnessing latent contempt towards sparking animosity and even violence against groups identified with alleged oppressors. If, in addition, the 'we' happen to share thick ethical relations with those designated descendants, say we are fellow citizens, such transference of past enmities on to the present would have catastrophic consequences for peaceful coexistence.

But when the narrative of enmity is imagined between groups living across national boundaries, the memory of trauma often gives rise to what Isaiah Berlin called bent-twig nationalism. Berlin contends that some expressions of nationalism are reactions to humiliation at the group's alleged treatment as inferior. Abuses by others often produces in the abused a Volksgeist or national spirit which responds, "like the bent-twig of the poet Schiller's theory, by lashing back" and hit its bender (Berlin 1972, p. 18). A belligerent form of nationalism stems out of external constraints, not from internal forces, is ostensibly different from a benign expression of national identity. Like a willow tree branch stretched by a bender, its sudden release sends a whiplash towards anyone standing inside its perimeter.

Berlin uses the rise of German nationalism as an example of the bent-twig model, a nationalism imputed to the humiliating defeat of Prussia by the French in 1806, at the battle of Jena. The defeat elicited two contrasting responses by two philosophical contemporaries, Fichte and Hegel-the later was at the time a resident of Jena and witnessed with awe the day Napoleon rode through the town to a parade devoted for his glory. He later confided to his friend, Zelmann, in a letter declaring that the outcome of the battle evidenced "that culture is triumphing over barbarism and the intellect over spirit-less mind" (Hoffmeister 1952, p. 137). 
Kebadu Mekonnen Gebremariam

Hegel's antipathy to Prussian nationalism was not short lived, as he continued to mock the festive mood with which the nationalist students embraced the liberation of Nuremberg from French occupation in 1813. (Hoffmeister 1952, pp. 14-15) He scoffed at the nationalist movement, accusing them of forsaking a much worthier pursuit of the liberation of the mind in favor of what he described as "the vain idea known as the German Reich."

While the Prussian defeat in Jena invoked a sense of relief in Hegel, it rather elicited in Fichte a sense of loss and humiliation. In order to bear the wounds of insult and humiliation, Fichte longed for the stability and comfort provided by a zealous doctrine of a 'home'. He would later devote his time to political agitation against the French by joining the nationalist university volunteer corps where he died fighting Napoleon's army.

Trauma allied with the stabilizing doctrine of a home have a strong psychological pull on people, even when they clearly knew the destructive consequences had by fervent nationalisms of any kind. To be clear, many contemporary variants of the politics of cultural identity follow the bent-twig model. How can we then preserve the stabilizing idea of a home without smuggling resentment fueled nationalist persuasion? As Susan Neiman recently remarked, "when memory becomes interchangeable with trauma, no country can hope to heal any wounds. We need ground to stand on before we can stand up to or own shame" (Neiman 2019, p. 382). A collective recognition that acting from trauma rather diminishes the hope to heal past wounds signifies the people's arrival within the vicinity of catharsis.

Täklä-Hawaryat Täklä-Maryam was barely into his teenage years when he accompanied Ras Mekonnen - the ruler of Harar and close confidant to Emperor Menelik II - to the Adwa campaign where Ethiopian forces inflicted a shattering defeat to the Italians on the $1^{\text {st }}$ of March 1896. Täklä-Hawaryat spent his formative years at Ras Mekonnen's court in Harar, where the latter raised him as his own son. On that momentous date on which the Ethiopian army inflicted a shattering defeat to the invading Italians, Ras Mekonnen along with a couple of his inner circle including Täklä-Hawaryat went to a nearby church. After the completion of the morning mass, it is customary to perform a synchronized collective bowing and prayer recitals called Dorgət (P C77). They had barely kicked off the transition into Dərgət when a messenger came along and heralded that the war had begun. As Ras Mekonnen hooped on to his horse and began galloping toward the battle field, Täklä-Hawaryat tried to keep up running as fast as he could. There was chaos inside the garrison, yet he managed to pick up his rifle from the communal tent. As he marched towards the battlefield the shooting had slowly died down and he 
quickly learned that the battle is already won. As delightful and surreal the victory was, for a fleeting moment Täklä-Hawaryat had a feeling of discontent at missing the action in a whiff of a time. His regret of not having fired his Winchester rifle and 150 bullets with which he vowed to kill 150 Italians - a personal gift from Ras Mekonnen - at the foreign invaders was partly fueled by patriotism and partly by a youthful penchant for danger. In his memoire, he reminisced rather fondly about that sweet victory without any trace of trauma, or hatred and bitterness towards the Italians. (Täklä-Hawaryat, 2005, pp. 50-51, 56-57 \& 67ff). Emperor Menelik expressed a similar sentiment during the peace negotiations with Italy in the aftermath of the battle. Concerning the fate of Italian prisoners of war, a magnanimous victor declared to the Italians:

You have come all the way here to beat us into submission. You claim that you are going to liberate people in Ethiopia from Slavery. However, let alone the Ethiopian people, you are not even capable of saving your own wretched rascals self-imprisoned in the garrison. If my own moral fortitude was as wanting as yours, I should have let them all die of thirst. Tell that to Baratieri. I am a Christian and I am not a king of savage people. Consequently, I will not let these Christians die...they can evacuate (Pankhurst et.al., 2005, p. 162).

However, the Askari soldiers, composed mostly of Eritrean and Libyan mercenaries, were not granted similar restraint and humanity. Instead, considered as traitors, the Askari prisoners were brutalized. Paradoxically, the Christian Emperor and savior of the glorious African kingdom met out the most gruesome punishment to his own kinfolk.

The post-Adwa spirit of Ethiopia can be characterized by a confidence brimmed with national pride, and an unfailing sense of independence that is expressed through an overt comportment of defiance. Adwa practically debunked the sermon of superiority that animated European imperialist campaigns in Africa. With a sentiment reminiscent of Ethiopians' pride in their long and lustrous history of statecraft, it may be right to conclude that the Ethiopian victory was the result of prior state building. Succinctly put, "Unlike the rest of the continent, European imperialism met its match in this corner of Africa." (Markakis 2011, p. 3) The victory at Adwa was made possible not only by Menelik's prior state-making but most importantly due to successful defense of Ethiopian independence by Emperor Yohannes IV and his formidable general Ras Alula in successive battles against the Egyptian, Italian, and Mahdist incursions. The Egyptian army was defeated at the 
Kebadu Mekonnen Gebremariam

Batle of Gundat and Gura in 1875-76, while the Mahdist invaders were routed in Metema in 1889 at the cost of Emperor Yonannes's own life. Ras Alula, who was a governor of Hamasén in the mid-1880s, alarmed by the Italian occupation of Massawa (done with tacit blessing from the British government) and their subsequent troop movements, warned the Italians that their act constitute a hostile infringement of Ethiopia's sovereign domain. Ras Alula then proceeded with intercepting the Italian advance, defeated them at the Battle of Dogali in 1887. This is to say that the defense of Ethiopia's independence against foreign incursion was decades in the making. In his political biography of Ras Alula, Haggai Erlich attributes Ethiopia's successful defense of her independence to two mutually reinforcing factors. One is what Erlich calls the "socio-political flexibility" of the Ethiopian society where social hierarchy is fairly open to talents, allowing talented leaders like Ras Alula to rise from humble origins. Secondly, what proved decisive "was the ability of [Ethiopia's] natural leaders to mobilize and organize militarily as well as politically, all levels of Ethiopian society" (Erlich, 1982).

Adwa's significance, however, reaches far beyond Ethiopian national frontiers. It gripped the imagination of black people within Africa and beyond who have fettered by the tyranny of racial oppression, colonial subjugation and the humiliation that it engenders. In the name Adwa is chiseled the image of freedom and dignity "in areas where white domination of blacks was most extreme and marked by overt racism, that is, in southern Africa and the United States of America. To the blacks of these countries, victorious Ethiopia becomes a beacon of independence and victory" (Bahru, 1991, p. 81; Levine 1974, pp. 12-14). The victory offered, and still continues to offer, a consolation as well as a model of independence and dignity for people whose quotidian life is punctuated by racial injustice, debasement, and a pervasive negation of their agency. A glorious source of light in history accompanied by the feeling of identification could serve as a palpable catalyst for optimism, and as a consequence transforms a life of suffering and inequity into an enchanted world of possibilities. Such identification instills a sense of one's own worth as opposed to degradation, an assertive self-definition as opposed to defensive recoil at one's victimization, a sense of responsibility to reassert damaged values as opposed to a cynical surrendering to evil, and above all the recognition of justice as a universal pursuit as opposed to a dangerous quest for vengeance.

The victory in Adwa is testament to the astonishing idea that a black nation can withstand the tides of colonialism and reclaim its independence and agency while at the same time conferring a moral gloss to the struggle for preserving the dignity and autonomy of all Black people. (Teshale, 1996; Berhanou, 1998, 
pp.130ff). To the degree that people cannot be made to accept their fate through sheer brutality alone, the most potent weapon for oppressors remains the mind of the oppressed. However, the memory of triumph against injustice inspires the opposite of contempt. Adwa's influence in inspiring a range of movements from the symbolic establishment of 'the Coptic Ethiopian Orthodox Church of Abyssinia' in the United States, following the foundation of Ethiopianism as a religious movement in 1892 by a South African Methodist pastor Mangena Mokone in Pretoria, and its expansion thereafter (Berhanou 1998, p. 132), to the early days of pan-Africanism, is indirect evidence of how one moment of glory can be harnessed to overturn trauma into catharsis.

This is not to say that Ethiopian history, both pre- and post- Adwa, can be condensed into spotless succession of independence and dignity. Nor is it meant to suggest that the towering historical figures are beyond repute. We must be candid about the country's particular history in all its beauty and ugliness. That it is equally important to acknowledge that the process of state-building partly satisfies Charles Tilly's predatory theory, which underscores the interplay between statemaking and war-making. Tilly argues that modern states are constituted by competition among 'wielders of power'. Some aspect of modern Ethiopian history aligns with the "war made the state, and the state made war" model (Tilly 1975, p. 42; Tilly, 1985). Emperor Menelik II's consolidation of the Ethiopian state involves some element of war-making (keeping external enemies at bay, of which Adwa is an epitome), state-making (overcoming internal adversaries, north and south), protection (securing internal alliances) and extraction (capital accumulation through the Gebbar system, and human capital through political alliances). No account of the political economy of Ethiopian state consolidation is complete without underscoring the critical role played by the internal wars of inclusion (Zewde 1991, Hiwet 1975). Menelik was cognizant of the threat European colonial expansion posed to Ethiopia. In a cryptic wax-and-gold-laden statement, he warned: "If powers at a distance come forward to partition Africa between them, I do not intend to be an indifferent spectator" (quoted in Hiwet 1975, p. 6). Clearly, Adwa cemented Menelik's grasp on power which, in turn, had given his southward campaigns a political cart blanche. We must not, therefore, throw under the rug the suppression of people that resulted from the inclusion of the periphery into the modern Ethiopian state. One direct consequence of the victory itself and the attendant territorial demarcation that followed is the paradoxical loss of territorial integrity (namely the erasure of Alula's victory at Dogali) which has led to the division of Tigrigna speaking populations of northern Ethiopia into two different countries. Menelik's reluctance to insist on an Italian withdrawal from Eritrea had 
certainly fomented anger for the perceived abandonment and distrust due to the disconnect from new political center. Menelik's indiscretions, whether or not they were done out of necessity, would later come to bite the country by informing Eritrean and Tigrayan independence movements from Ethiopia from the mid-1950s on. It is, therefore, imperative that we re-contextualize Awda's legacy and our troubled past by subjecting it to a more inclusive interpretation. For the same reason, we must also recognize that some routinely seek to exploit the memory of injustice and mistreatment for deliberate myth-making such that they plant the seeds of bent-twig nationalism. One notable example is the thesis of "Black colonialism" a perspective that sees Menelik's expansion to the South, and subsequent conquest of the territory and peoples, within the framework of the scramble for Africa. This view has significant traction within the Oromo, Sidama, Wolayita, Ogadeni intelligentsia, comprising the central tenet of OromummaaOromo nationalist ideology. (Jalata, 2015). However, the image of native colonialism presupposes advancing certain preconceptions about the nature of African societies as well as the process of state formation in Africa. The accepted view that state formation in Europe underwent a two-pronged process of territorial expansion and political centralization has routinely been denied for Africans. Similarly, interpreting state-making and war-making in Ethiopia using the analogy based on the scramble for Africa lends itself to two contradictory images: the image of a civilized nation, and the image of barbarism (of wars waged merely to satiate the human base instinct to subjugate, rape, loot, and plunder) - the very same prejudice that paradoxically ascribed European colonialism in Africa a convenient moral posturing, code-named "the civilizing mission". For a colonial force is presupposed to have mastery on civilized culture and statecraft, the Ethiopian empire can't consistently be conceived both as a colonizing force and as a barbaric subject for European scramble for Africa. Certainly, the process of state making in Ethiopia was a brutal affair especially to those who were at the receiving end of the wars of inclusion. But reducing the legacy of Adwa by interpreting Menelik's southward campaign as a continuation of the imperial carve-up of Africa is both inaccurate as well as morally insidious.

\section{Memory as redemptive: two tasks, working-off-the-past and redeeming the present}

Susan Neiman wrote that every nation with checkered past can learn from Germany's attempt at working-off its Nazi past. While each nation must attend to the particularities of its history, "the similarities can teach us about guilt and 
atonement, memory and oblivion, and the presence of the past in preparing for the future" (Neiman 2019, p. 37).

That we must guard against the familiar ways of abusing memory of the past does not imply that the alternative is to erase the memories of injustice altogether. Reliving the memory of harm that's been done to us can ignite bitterness that may stoke bitterness and encourage vengeance. History is replete with instances in which the memory of harm or defeat is used to galvanize support for perpetrating odious crimes or for denying that one had been committed. For instance, in Italy, the defeat at Adwa had gradually ebbed from public memory. "Yet, when Fascism took power, Adwa started again being 'remembered', though in a perverse way: the defeat of Adwa could be avenged only through an equal if not greater enemy defeat" (Triulzi 2003, p. 105). Ancient Greeks used a term for weaponizing historical memory - "to remember against", as synonymous with an "act of vengeance'. During the reconciliation (of $403 \mathrm{BC}$ ) following the end of proSpartan oligarchic brutality of Athens by the so called "Thirty Tyrants", as a means to deter retaliation, Athenians declared an edict to erase the memory of suffering from public remembrance (Triulzi 2003, p. 98). Similarly, memories of humiliation and economic ordeal brought on the German public due to the punitive measures imposed at the Versailles Treaty at the end of WWI was exploited by the Nazi party. One familiar theory for Germany's defeat is what's called the "stab in the back" myth whose origins can be traced back to 1917. It was the Nazi propaganda, however, that took the crucial step of defining the main protagonists of the "stabbing of Germany", imputing it on readymade scapegoats - the Jews. Similarly, invoking the memory of slaughter of tens of thousands of Hutus by the Tutsis in Burundi in 1972, 1988, and 1991 was a technique often used to fuel the anti-Tutsi campaign during the Rwandan genocide. Meanwhile, America's failure to face its past is partly predicated on the Lost Cause myth that Southerners deliberately constructed after the Civil War. Southerners created this myth as a psychological response to the trauma of defeat by recasting the Confederates as heroes whose cause was just, while ignoring slavery as the cause of war. However, the antidote to maladjusted memory is not forgetting but transformation. We ought to take to heart the wise counsel that Neiman imparted to us: "Forget the past and move on isn't helpful in the realms of individual psychology; as political advice, it is worthless." Asking people to forget and forgive without a process of collectively coming to terms with past crimes is precisely to demand that trauma is experienced without meaning. "When pasts fester", she writes, "they become open wounds" (Triulzi 2003, p. 98). 
Unaddressed trauma perpetuates active suffering out of which some will contrive a framework with which to give meaning to it. That will in turn create a fertile ground for bent-twig reactions, with narratives devised "in a concerted effort to defeat truth itself" (Triulzi 2003, p. 187). As Neiman observes, "The weavers need not be those who remember the suffering directly. Often it's the suffering of the ancestors, more imagined than experienced, that drives the search for a framework with which to understand it" (Triulzi 2003, p. 63).

Both the destruction of memory or what Adorno regards as acts of forgetting and the effort to weave a myth around it are equally pathological responses to a painful national past. In its own peculiar way each avoidance of reality seeks to adopt a totalizing doctrine that can readily fit facts to the story, where in fact it ought to be the other way around. Facts do give us reason to form our beliefs, which in turn inform our actions. Whereas, false consciousness rebels against the process of belief formation that flows directly from facts by ignoring the critical role played by the dialectical interrogation of received 'appearances'/narratives, where beliefs are tested, modified, or rejected. Theodor Adorno laments at the 'positivistic' consciousness of contemporary society which is characterized by a lazy, unreflective, criterion of reason according to which appearance is identified with truth. Clearly, distortions of memory can manifest not only as pathological fixation with one's own "pain and heartbreak [as] unprecedented in the history of the world", but also as a blanket and callous dismissal of others' memory induced experience of the past as inherently invalid. Both involve ascribing totality of truth to one's own experiences, leaving no space for what was assumed to be the truth about the object of one's experiences to be problematized and critically appraised. Under such conditions, living the present for and through memories of the past amounts to a death sentence to experience itself-experience conceived as a 'becoming'. That is because ascribing value to experience entails that how we choose to interact and live together in the present matters.

In "The Meaning of Working Through the Past" (henceforth WTP)—a 1959 paper that generated wider interest, Adorno noted both the dangers of what he regarded as "acts of forgetting" human suffering (forgetting taken not in the sense of loss of memory) and the loss of individuality. He envisions the reconciliation of subject and object, through a process of "negative dialectics", as a segway for social reconciliation. In the context of postwar Germany, those who seek to undermine Nazi crimes and of the significance of preserving the memory of the Holocaust adopt strategies that Adorno characterize as acts of forgetting. The strategies include (1) duplicity manifested in the form of a strange "guilt-complex" expressed as though there was nothing to feel guilty about (WTP, pp. $90 \& 91$ ); (2) 
euphemism: a horrible pogrom of November 1938 given "almost good-natured expression Kristalnacht, attests to this inclination" (WTP, p. 90); (3) indifference masquerading as "not having known anything about it". (WTP, p. 90); (4) an attempt at drawing moral equivalency, as if one's moral debt can be wiped clean by a later event in which one is ostensibly victimized, for example, as though the allied bombing of Dresden cancelled out Auschwitz (WTP, p. 90), or as though the defeat of Italy compensated for the Addis Ababa Massacre of 1937 or that Menelik's southward campaign of expansion and the subsequent imposition of Imperial norms on the southern tribes offsets the centuries of conquest and assimilation done by the Oromo while also acting oblivious to the existence of the Yejju dynasty; (5) victim blaming: the thought that in some way the victims had it coming, for example, the prosperity of some Jewish communities perceived as an elaborate ruse at world domination, constituting a threat justifying "remedial" action (WTP, p. 90). As a consequence, "The murdered are to be cheated out of the single remaining thing that our powerlessness can offer them: remembrance" (WTP, p. 90).

Neiman, similarly, has shown that the strategies used to deflect guilt stem from the tendency to consider one's own suffering as paradigmatic and, in the case of the Germans, as if the suffering they endured during and after the war made everything retrospectively permissible. "The tendency to set one's own suffering über alles", Neiman writes, "isn't particularly German, nor is it particularly new. Competitive victimhood may be as close to a universal law of human nature as we're ever going to get; it is surely an old and universal sport" (Neiman 2019, p. 63). Her description seamlessly applies to the fierce, and at times venomous, disagreement elites have over recent Ethiopian history. I might add that the loss of individuality in persons whose self-definition is encapsulated by the trauma suffered by one's ancestors also mirrors what Adorno dubbed an act of forgetting. This time, concealed by trauma or tribalism, the person becomes impervious to the complexities and nuances of experience and instead declares that one's suffering is the sole currency for interpreting the reality of past and present. Beneath the error in epistemic judgement is found a profound moral myopia, epitomized by the implicit assumption that moral debt for past crimes stops at the point of history of their choosing. It is not helpful to assume that the memory of one's suffering is all that matter (the particular is universal) any more than it would be helpful to try to deflect guilt by pretending that the memory of suffering lacks any moral grip on us. Such is an insidious way in which an act of forgetting figures in collective consciousness. Thus, in essence the problem of the distortion of memory is closely tied to the problem of the denial or destruction of experience. 
Only people who are associated with perpetrators of a historical wrong are morally permitted to speak of its singularity, both to underscore that the crime has no moral equivalent and to condemn it in absolute terms that it ought not have happened. Those who declare singularity are in effect taking responsibility for historical injustices, while those who insist on its universality are seeking exoneration, suggesting that if everyone does it then we can't talk about it in forbidding terms. On the other hand, victims should frame their suffering in universalistic terms such that they confer meaning to the memory of evil without trauma or tribalism. (Neiman 2019, pp. 28 \& 381ff)

In Hope and Memory, Tzvetan Todorov claims: "In working with the past, construction of meaning has to follow the establishment of the facts" (p. 122). There is another rationale for insisting that victims of extreme forms of evil, such as Holocaust survivors, ought not venture on the parochial attempt at understanding the moral psychology of their tormentors - on what motivated them to do what they did. Primo Levy, a survivor from Auschwitz and witness to the Nazi crimes, suggested that "one cannot, what is more one must not, understand what happened [at Auschwitz], because to understand is almost to justify" (If This is a Man, 395; quoted in Todorov, p. 123). To what purpose, then, keeping alive the memory of harm must serve? Todorov's answer is remarkably akin to the maxim of universalizability that Neiman insisted upon. The transformation of trauma into catharsis, argues Todorov, consists in abstracting a universal maxim from a particular experience "- a principle of justice, a political ideal, or a moral rule - which must be legitimate in itself and not just because it relates to a cherished memory" (Todorov, p. 173).

Just how historical monuments are erected with the view to justify ourselves before them, the memory of evil must be used to interrogate and hold ourselves to account that we are to live righteously. Thus, keeping alive a memory of harm must essentially serve a moral function, namely that its end ought to be judged in terms of values. The past holds no value in and of itself, independently of how we live now. We are objects to the memory of the past and its value is partly a function of how well we are orienting ourselves in the present. This is not only because we are, in some meaningful sense, a product of our past, but it is also because memories are interpretations of - not substitutes for-how things were. One does justice to a memory of the past by advancing the cause of justice, which is by definition impartial to the identity of the would-be victims.

Of course, every person has a right to affirm identity but that's not necessarily righteous or dignified. Clearly, valuing and holding on to one's identity are compatible with maintaining a moral outlook about how others ought to be 
treated. The problem is when affirming identity is taken as an article of faith for which unconditional loyalty is a fitting attitude. Fidelity to identity routinely makes people blind to the suffering of others, for recollections of the harm done to people does not by default make them sympathetic to the suffering that is not aimed at the same group or not of the same kind - not even Holocaust survivors were immune to apathy. There are examples in which those who lived through the horrors of Nazi concentration camps displayed extraordinary humanity to others, as there are survivors who were blinded by their Communist political persuasion so much so that they refused to acknowledge, much less condemn, the existence of concentration camps in the Soviet Union (Todorov Op.cit., 173ff). A warped understanding of reality can thus be caused by prejudices and indoctrinations drilled into one's life. Such are instances of irrationality that Ludwig Wittgenstein described as "being in the grip of a picture."

All 'acts of forgetting' - whether they manifest in the form of deflection of guilt or as abusing of memory (by exalting the memory of one's own suffering über alles) - share a common thread. They constitute a form of irrationality that occurs when the individual lacks agency and instead occupies the consciousness of an unreflective echo chamber. Both who seek to deflect guilt by assuming a moral posturing of "forget and forgive" and those who wish to stretch the fabric of reality by speaking of the singularity of their own suffering would equally "prefer to get rid of the obligation of autonomy" (WTP, p. 99). Adorno associated the problem of memory with social reification. He explains the structure of reification as: "Above all this is a consciousness blinded to all historical past, all insight into one's own conditionedness, and posits as absolute what exists contingently. If this coercive mechanism were once ruptured, then, I think, something would be gained" (Adorno, 2003, p. 28).

What is principally required to work through the past is the affirmation of autonomous subjectivity. For Adorno catharsis is to be found indirectly through the adoption of authentic art that has the wherewithal to provoke contradiction. The experience of shock and loss of self-certainty that some works of art provoke in the subject is precisely what is needed for launching the process Adorno called dereification. One thus arrives at critical subjectivity, and thus a non-repressed society as a consequence, not through a formal process of critique and reflective thought but by going through moments of being shaken by radical works of art.

The life of James Baldwin - the American literary giant and activist-reflects quite brilliantly such artful transition from 'conditionedness' to 'dereification'. Baldwin found American prejudice against black people unbearable so much so that he left the US at the age of 24 to settle in France. Later on, maturity and 
Kebadu Mekonnen Gebremariam

wisdom made him bear witness to his own 'conditionedness' and he wrote: "You think your pain and your heartbreak are unprecedented in the history of the world, but then you read." Such moment of introspection, or negative dialectics as Adorno would frame it, might have rescued Baldwin from the jaws of despair and bitterness. He responded to racial prejudice, as it were, with a moral gaze. He reckons, "It was Dostoevsky and Dickens who taught me that the things that tormented me most were the very things that connected me with all the people who were alive, or who had ever been alive. Only if we face these open wounds in ourselves can we understand them in other people" (Baldwin, 1963).

\section{A moral witness and the Adwa test for national reconciliation}

A moral witness is someone who had a direct personal encounter with actual episodes of evil. A paradigmatic example is one who retains a moral outlook despite the suffering one has seen and endured. The adjective moral applies to "the content of the testimony, not with the epistemological status of what the moral witness witnessed" (Margalit Op.cit., 163-164). And what renders a witness's testimony moral is its ability in restoring the very idea of a moral system that acts of evil sought to destroy. Thus, one can't be considered as a moral witness if he or she proclaims that despair and nihilism are the key takeaways from the encounter with acts of evil.

On the other hand, one cannot be a moral witness to a hearsay, or in virtue of documenting other persons' firsthand account of events. Although uncovering the factual truth as well as the structure of evil can be expertly done by political witnesses and historians who, either by temperament or training are more suited to the task, "a moral witness is more valuable at telling it like it felt, that is, telling what it was like to be subjected to such evil" (Margalit Op.cit., 168). If what's expected of a moral witness is to imbue a moral outlook on past suffering, should we then expect any less from a political witness, historian, or someone whose encounter with the past is identification by proxy or what may be described as undergoing something "inner"?

There is a recent malaise in the Ethiopian public discourse relating to the recollection and reliving of a distant past the protagonists of which are long gone. It has to do with the pretense of being a moral witness by proxy for the simple purpose of weaponizing memory. Such attempt fails both on account of satisfying the necessary conditions for being a moral witness as well as on account of the testimony's fittingness to being characterized as moral. What is crucial about moral witnesses is how they imparted the sense and sensibility of the past, not for 
the description of what the moral witness witnessed. How one feels about how the direct witnesses felt is a matter that is twice removed from being a moral witness.

Moreover, the general intent to weaponize past memories, frantic with hatred and prejudice, and with the view to confer resentment a political outlet is contrary to the moral conjunction of being a 'moral witness'. A moral discourse is more compelling when it is grounded on truthful narrative about past events. Without this precious moral outlook to memories, what appears in the name of remembrance is just a corruption of thought masquerading as undergoing something "inner".

We do not see the same level of moral corruption in cases where there are survivors to past crimes, as we've seen the extraordinary ways in which survivors to the Red Terror massacres in Ethiopia-hence moral witnesses, can teach us about "guilt, atonement, memory and oblivion". Nameless ordinary people can also have the moral authority to bear witness to life under authoritarian regimes. What's more, moral witnessing is more poignant when a collective agony is expressed through folklore. One such case is the story of mothers in Gondar who went through the agony of bearing witness to the assassination of thousands of young men opposed to the regime by a group led by the notorious enforcer of the Derg military junta named Melaku Tefera. He was known to have personally assassinated young men in broad day light, at times for frivolous reasons such as in response to a mother's plea to discipline her rambunctious teenage son. The

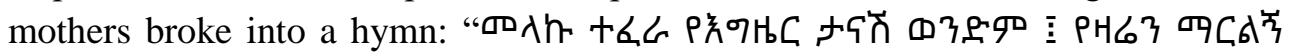

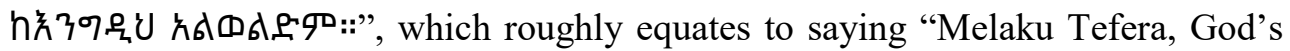
younger brother; I won't bear another one, have mercy on my child today." To my mind, the moral of the story is that the value of life was rendered so cheap as to be snatched away like a fly or a thing to be removed, mothers sought to trade the very capacity to bear a child if that can spare the one they brought into being. The image of Melaku as "God's younger brother" is to highlight the almighty-like authority he had over life and death. The hymn conjures up horrible images of how things were then in Gondar - taken as a microcosm of the brutality of the totalitarian regime across the country.

The problem of reconciliation still lingers either with or without the presence of moral witnesses. Whilst the presence of survivors makes possible for launching a rigorous process of reconciliation as it was done in post-Apartheid South Africa, but without them societies are usually at a loss what ought to do and where to begin. What can we possibly do about memories of the lingering past for which there are no living moral witnesses? How are we to address the trauma that was passed through generations? Forget the past, bury the trauma that's either real 
Kebadu Mekonnen Gebremariam

or imagined, and live your life until it's time to 'shuffle off this mortal coil', would not serve any purpose. Any other simplistic solution to a complex problem won't cut it either.

But there is one suggestive way to begin the process of healing. That is precisely by drifting our focus away from the victims, for we are more likely to spring to action following the example of heroes than being motivated by pity for victims (Neiman, 2019, p. 371). It is more likely that we'll be inspired by people who've led exemplary lives fighting evil against all odds. Even better, we can draw inspiration from moments of collective triumph, which could be a rising up from a natural tragedy that revealed an admirable national character, or an overcoming of a foreign threat that everyone can take pride in. Adwa comes in as a paradigmatic case of the latter kind.

Victims are ubiquitous, especially the sort of victimhood that was intergenerationally transmitted in which case we all can portray ourselves as victimized in one dimension of life or another. But there is no such thing as the intergenerational transference of heroism, as each generation is expected to forge its path, heroic or otherwise. Whereas being a hero is a rarity, the underpinning essence of heroism is pretty much uniform across cultures. Just as Tolstoy's creed has it that 'happy families are all alike; every unhappy family is unhappy in its own way', so in the same way, all heroes essentially come as redeemers, but victims are victimized in different ways and for different reasons. In addition, the hero's virtue is constitutive to his personality. However, it would be a mistake to conceive of victims as if their suffering defines them. That would amount to a reductionism of persons to things that have been done to them, and for which they generally have no control. Although the lives people lead are partly outcomes of forces outside their control and that these unchosen elements clearly determine the persons' life chances in some meaningful ways, they are not the primary sources of meaning to life. A society that is consumed by trauma, without symbols of transformation, is perceptively frozen in time.

The archetype of a hero is as old as human civilization itself; it figures prominently as a foundation of culture ever since societies began to tussle with the vastness of reality and our place in it by weaving mythologies around it. The hero archetype is often used throughout the annals of human culture to confer a moral account to the tribulations of life and serves as a purveyor of inspiration "through which society is reborn" (Campbell, 1968).

Adwa is a symbol of transformation and so are the heroes who fought in it. Considering the circumstances in which people, otherwise divided by culture and religion, social status and a place in the power structure, all flocked to Adwa to 
defend the motherland from the clutches of colonialism, it is undoubtedly the single most unifying event the scale and significance of which wasn't seen ever since. When present day adherents of the so called 'national question' speak on behalf of victims of ethnic prejudice and subjugation, they allege that modern Ethiopia is a product of one singular cause-ethnic domination. Such narrative simplifies a complex but real problem whose origin is interwoven with the long and protracted process of state making in Ethiopia. In articulating how ought we to work-off-the-past, we must not forget that some of the victims are the very people who laid down their lives in Adwa so to preserve freedom, dignity and a sense of an independent home land to their descendants. If we, their descendants, are asked to justify ourselves before them, would one think that they'd be satisfied to see us tearing each other apart? This is to say that what I termed as the Adwa test for national reconciliation is a perspective for aligning how ought we to treat each other as fellow citizens. Should we approach social reconciliation from the perspective of division and enmity, instead of as people whose destiny is inseparably tied, we'd then fail the ancestors in whose name we fight.

Finally, where there appear to be no perceptible way for transforming trauma into social catharsis, emulating the path of the hero seems to be the only morally palpable path towards transforming the past as present. Adwa is the ground on which we stand, "a flame that makes us want to live righteously". Adwa may inform each generation of Ethiopians differently depending on the defining socio-political problems of the time that encumber preserving freedom and dignity for all and as a consequence hinder the process of social healing. In each defining historical moment where we face challenges that distress the social fabric, the memory of Adwa should inform us in adopting the hero's journey. The heroic path can be many, not one. But, when invoking Adwa for social reconciliation, we must, on the one hand, resist the temptation to conceal its legacies - either good or bad. On the other hand, historical documents are responsive to reinterpretation and thus Adwa's significance should not viewed with the Medusa's gaze that turns everything into stone - a monument. 


\section{References}

Abebe, B. (1998). Histoire De L'Éthiopie d'Axoum à la Révolution. Maisonneuve \& Larose, Centre Français des Études Éthiopiennes.

Améry, J. (1980). At the Mind's Limits. Bloomington: Indiana University Press.

Adorno, T. (1998). The meaning of working through the past trans. Henry W. Pickford, in Critical Models: Interventions and Catchwords. New York: Colombia University Press.

Adorno, T. W. (2003). Can one live after Auschwitz? A Philosophical Reader. (Rolf Tiedemann, Ed. \& Rodney Livingstone et al., Trans.) Stanford: Stanford University Press.

Avineri, S. (1962). "Hegel and Nationalism." The Review of Politics 24(4), 461484.

Baldwin, J. (1963) "The Doom and Glory of Knowing Who You Are", Life Magazine, May 24, 1963.

Berlin, I. (1972). "The bent twig: A note on nationalism." Foreign Affairs, 51(1), 11-30.

Campbell, J. (1968). The hero with a thousand faces. Princeton: Princeton University Press.

Erlich, H. (1982). Ras Alula and the scramble for Africa: A Political biography: Ethiopia \& Eritrea, 1875-1897. Lawrenceville, N.J.: Red Sea Press.

Freud, S. (1974). Complete psychological works of Sigmund Freud (Vol.3). London: Hogarth Press.

Hiwet, Addis (1975). Ethiopia: From autocracy to revolution. London: London Review of African Political Economy.

Hoffmeister, J. (Ed.). (1952). Brief von und an Hegel. Hamburg.

Hume, D. (1748). An Enquiry concerning human understanding. London: A. Millar

Jalata, A. (2015). Theorizing Oromuumaa. Journal of Oromo Studies, 22, 1\&2.

Levi, P. (1987). If this is a man; The truce. Trans. Stuart Woolf. London: Abacus.

Levine, D. (1974). Greater Ethiopia: The evolution of a multiethnic society. Chicago: University of Chicago Press.

Markakis, J. (2011). Ethiopia: The last two frontiers. Woodbridge, Suffolk, UK: James Curry.

Margalit, A. (2002). The ethics of memory. Cambridge, MA.: Harvard University Press.

Neiman, S. (2019). Learning from the Germans: Confronting race and the memory of evil. London: Allen Lane 
Pankhurst, R. et al. (Eds.) (2005). The battle of Adwa: Reflections on Ethiopia's historic victory against European colonialism. Ney York: Agora.

Pollock, F., \& Adorno, T. (2011). Group experiment and other writings: The Frankfurt school on public opinion in postwar Germany. Edited and Trans. By JK Olick and AJ Perrin. Cambridge, MA.: Harvard University Press.

Radstone, S., \& Schwarz, B. (Eds.) (2010), Memory: Histories, theories, debates. Fordham University Press.

Solzhenitsyn, A. (1974). The Gulag Archipelago 1918-156: An Experiment in Literary Investigation III-IV. Trans. Thomas P. Whitney. London: Harper \& Row.

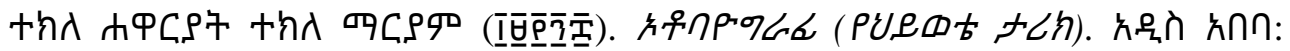
久号方

Tibebu, T. (1996). "Ethiopia: The "anomaly" and "paradox" of Africa", Journal of Black Studies, 26(4), 414-430.

Tilly, C. (Ed.). (1975). The Formation of national states in Western Europe. (Studies in Political Development, 8). Princeton: Princeton University Press.

(1985). "War Making and State Making as Organized Crime", in Peter Evans et.al. (eds.), Bringing the State Back. Cambridge: Cambridge University Press.

Todorov, T. (2003). Hope and Memory: Reflections on the twentieth century. Trans. David Bellos. Princeton: Princeton University Press.

(2010). Memory as a Remedy for Evil. Calcutta: Seagull Books.

Triulzi, A. (2003). Adwa: From monument to document. Modern Italy, 8(1), 95108. DOI: $10.1080 / 1353294032000074106$

Zewde, B. (1991). A history of modern Ethiopia 1855-1974. London: James Curry. 